\title{
空洞掘師と実駼調查およで線形逆解析による 堆積軟岩の変形特性
}

\author{
越智健三*・壸内達也*・龍岡文夫**
}

\begin{abstract}
堆積軟岩中に深度 $50 \mathrm{~m}$ の立坑と横坑を掘削した. 立坑および横坑の変形を計測した. 横坑では, $30 \mathrm{~cm}$ と $60 \mathrm{~cm}$ の載荷板の平板載荷試験とオーバーコアリングによる初期地 圧測定を行った。初期地圧の測定值を考慮した線形逆解析による変形特性と室内試験お よび原位置試験による変形特性をひずみおよび忍力レベルを合わせて検討した．その結 果，この堆積軟岩は非線形連続体として扱えることが分かった.
\end{abstract}

Key Words : soft-rock, Young's modulus, excavation, ground pressure, back-analysis

\section{1. まえがき}

堆積軟岩中の地下構造物の変形や土圧の解析を精度よ く行うためには，正確な変形係数が必要である．筆者ら は，首都圏西部の大深度地下構造物の設計・施工に関わ る地下情報の収集を主目的として, 上総層群泥岩内に立 坑と横坑を試験的に掘削し, 実測地盤挙動の数値解析と 系統的で多様な原位置および室内試験を行い，これらの 結果を総合的に比較検討することにより，堆積軟岩の変 形係数の全体像を明らかにする研究を行った. 前報 ${ }^{1), 21}$ では, 深度 $35 \mathrm{~m}$ の立坑掘削工事の概要と現場計測值の 線形逆解析および原位置試験と室内試験の結果について 示し，（1）従来の設計で用いられてきた変形係数は小 さすぎること，（2）ひずみレベルを合わせれば，正確 に測定された原位置試験と室内試験および現場計測の線 形逆解析による変形係数は概略一致し, 連続体の解析手 法が適用できること，などを報告している．

一方, 地盤を連続体と仮定した解析では, 変形係数と 同時に初期応力すなわち地圧が非常に重要なパラメー夕 となるが，前報1)ではこの点の検討が不十分であった。 土木学会編 [初期地圧測定法の現状と課題 $]^{3)}$ では, 硬岩 を対象に構造物の設計・施工での地圧測定の重要性が指 摘されている. 堆積軟岩でも今後の大深度地下開発に際 しては，変形係数と同時に地圧を精度良く事前に把握す ることが不可欠であると考えられるが，現状ではその研 究例が非常に少ない. 一般に堆積軟岩の地圧は等方的と 仮定して解析する場合が多い．前報”の線形逆解析では 水平之鉛直の初期応力の比が 1 より大きくなり，地圧を 明らかにすることが検討課題として残った。

本研究では, 前報 ${ }^{1)}$ よもより深い深度 $50 \mathrm{~m}$ までの

*正会員 東急建設(株) 技術研究所 土木研究部 土木施工 研究室 ( ( 229 相模原市田名字曽根下 3062-1)

** 正会員 工博 東京大学教授 東京大学生産技術研究所 5 部
立坑掘削と横坑掘削を行い, それに伴う地盤の変位を計 測した。さらに，深度 $50 \mathrm{~m}$ 位置で平板載荷試験および 初期地圧測定等の現場実験を゙実施，不明確であった初期 地圧特性を考察した。 その地圧測定結果を基に，現場変 位計測結果を用いた線形逆解析により变形係数を求め, ひずみレベルと応力レベルに対する変形特性として室内 試験と原位置測定による変形特性と比較した. その結果, 堆積軟岩の剛性は従来慣用的に用いられてきた值よりも かなり大きいことを確認した。

\section{2. 地盤 状 況}

図一1に実験空洞の鳥瞰図および地質概要を示す。掘 削工事は 1992 年 3 月 17 日から $35 \mathrm{~m}$ 以深の立坑掘削を 開始し，E横坑掘削終了は同年 9 月 20 日であった。 そ の後同年 12 月 25 日まで $\mathrm{E}$ 横坑内で原位置試験を行っ $た^{6)}$. 構築サイトは神奈川県相模原市郊外の段丘地に位 置する．横坑の軸線方向は $\mathrm{N} 40^{\circ} \mathrm{W}$ 方向である.

図一2には，ボーリングコア試料による圧密三軸圧縮 強度 $q_{\max }=\left(\sigma_{1}-\sigma_{3}\right)_{\max }$ の深度分布を示す. 今回施工し た立坑および横坑部での泥岩の平均的圧縮強度は, $q_{\max }$ $=55 \mathrm{kgf} / \mathrm{cm}^{2}(5.4 \mathrm{MPa})$ であった.この深度位置の泥 岩は塊状の泥岩が主体であり，所々にスコリアや軽石を 含み, 貝化石片や微細な炭質物も含む.この位置では, 深度 $35 \mathrm{~m}$ までの泥岩部の.ような $15 \mathrm{~cm}$ 程度の細〜中粒 の砂層および $5 \mathrm{~cm}$ 程度のスコリア層の挾在や凝灰質泥 岩の介在は見られなかった。層理はNW-SE 方向北東 へ約 10 度傾斜する単斜構造である. 割れ目性状の一覧 を表一1に示す。深度 $50 \mathrm{~m}$ 位置でも， $35 \mathrm{~m}$ 位置で確認 された断層系の明瞭なせん断性割れ目に対応する節理が 見られたものの, 開口はしておらず, よ゙の割れ目もほぼ 同様な性状を示した，全体的に割れ目はしっかりと密着 しており，ブロックサイズは中程度の大きさである. 
表一1 泥岩の割れ目調査結果一覧

\begin{tabular}{|c|c|c|c|c|c|c|c|c|}
\hline \multirow{2}{*}{ 項目 } & \multicolumn{2}{|c|}{ 試掘横 坑 (深度 $35 \mathrm{~m}$ ) } & \multicolumn{6}{|c|}{$E$ 横坑（深度 $500 \mathrm{~m}$ ) } \\
\hline & 首系 & 節 理 系 & 節理系 (1) & (2) & 管理系 $\quad(3)$ & 節理系 (4) & 笓理系 (5) & 均 \\
\hline 趟 - 的 & $779^{\circ} \|, 81^{\circ} \mathrm{ST}$ & 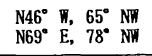 & N62 $\mathrm{E}, 76^{\circ} \mathrm{SE}$ & $\mathrm{N} 39^{\circ} \mathrm{E}, 83^{*} \mathrm{SE}$ & N64 E, $81^{\circ} \mathrm{NTH}$ & $\mathrm{N} 38^{\circ} \mathrm{E}, 84^{\circ} \mathrm{NW}$ & $\mathrm{N} 75^{\circ} \mathrm{W}, 86^{\circ} \mathrm{STH}$ & \\
\hline 間雨 (m) & $0.1 \sim 0.2$ (狭) & $1 \sim 2$ (広) & 0.31 (中) & 0.34 (中) & 0.29 (中) & 0.52 (中) & 0.15 (中) & $0.3 \sim 0.4$ (中) \\
\hline 連綜棈（m) & $0.2 \sim 0.3$ (低) & $0.15 \sim 0.2$ (低) & 0.67 & 0.63 & 0.37 & 0.63 & 0.55 & $0.3 \sim 0.4$ (低) \\
\hline さ & 平坦消らが箕肌 & 平坦滑らか & 平坦消らか几滑 & 加波状 & & & & \\
\hline 間隐堛 (口) & 0.39 (平板間湶) & $\begin{array}{l}0.29 \text { (しつ加密 } \\
\text { 着〜部開密着) }\end{array}$ & 0.79 (開間隌) & $\begin{array}{l}0.19 \text { (しっかり密 } \\
\text { 着) }\end{array}$ & $\begin{array}{l}0.2 \\
\text { 曾) (しっかり密 }\end{array}$ & $\begin{array}{l}0.06 \text { (非常にしっ } \\
\text { かり密着) }\end{array}$ & 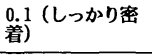 & $\begin{array}{l}0.16 \text { (しっかり密 } \\
\text { 着) }\end{array}$ \\
\hline 充 填物 & 粘土 & なし & なし & & & & & \\
\hline 漫 䢪 水 & 一部济水 & 一部激水 & なし & & & & & \\
\hline $7 \cdot \square_{9} \geqslant \forall 1 X^{\circ}$ & $\mathrm{Jv}=7.9 / \mathrm{m}^{3}$ (中) & $\mathrm{Jv}=1.8 / \mathrm{m}^{3}$ (大) & $\mathrm{Jv}=7.0 / \mathrm{m}^{3}$ (中) & & & & & \\
\hline
\end{tabular}

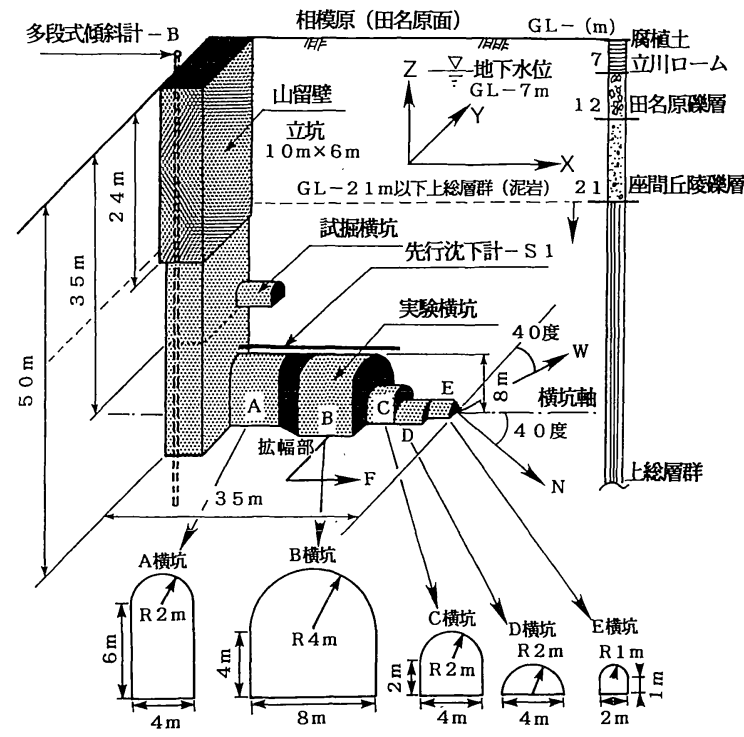

図-1 実験空洞鳥瞰図

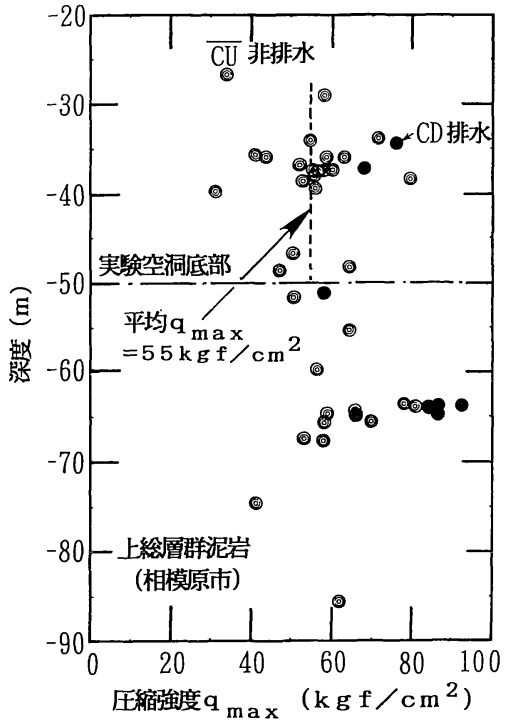

図一2 圧縮強度の深度分布

\section{3. 実験空洞の施工}

立坑および横坑の構造図を図一 3 , 図一 4 に示す.今 回の施工部分は $35 \mathrm{~m}$ 以深の立坑と横坑である. 図一4 (a) に示すように，立坑の支保は長さ $4 \mathrm{~m}$ ピッチ 1.2 $\mathrm{m} \mathrm{D} 25 \mathrm{~mm}$ 径のロックボルト挿入と厚さ $5 \mathrm{~cm}$ の吹付け モルタルのみで行い，上部立坑工事 ${ }^{1)}$ ような $\mathrm{H}$ 型鋼フ レームは設置していない. 泥岩の掘削は $0.15 \mathrm{~m}^{3}$ のバッ クホウで行い, ロックボルトは掘削深さから $1.2 \mathrm{~m}$ 遅 れで打設した。深さ $1.2 \mathrm{~m}$ を 3 日間で掘削および支保 する施工速度であった。計測は主に多段式傾斜計（図一 1, 図一 3 , 図-4にBで示す）による立坑水平変位測 定と各段（全 12 段）のロックボルト軸力計による軸力 測定で, 温度変化を把握する熱伝対も設置した. 後で示 すように，立坑水平変位は $35 \mathrm{~m}$ までの掘削時より非常 に小さく, H 型鋼フレームがないにもかかわらず，ロッ クボルト軸力は $100 \mathrm{kgf} /(1 \mathrm{kN})$ 程度の微小な值しか生 じなかった。 すなわち,この施工法では支保工は地盤変
位の抑制にはほとんど寄与していないと思われる.

横坑は深度 $46 \mathrm{~m}$ 位置で上半部と下半部に分けてロー ドヘッダー掘削した (図一1の A 横坑, 拡幅部, B 横坑). 掘削速度は支保工まで合わせて，1 スパン（H 型鋼の区 間 $1.44 \mathrm{~m}$ ）2.5日であった。湧水量の単位表面積比は $100 \mathrm{~cm}^{3} / \mathrm{min} / \mathrm{m}^{2}$ （ルジオン值は $L u=0.77$ ）で, 掘削切 羽面は乾いた状態であった。

横坑の支保工は安全上の制約の中で軽い構造とし, 図 一 4 ( b ) に示すように $\mathrm{H}$ 型鋼の両端部は底面から若干 浮かせたいわゆる自由端構造とした，側壁と底面との交 点は直角に掘削し，インバートは施工せず底面の浮き上 りを测定した結果，その量は天端沈下量の $1 / 10$ 程度し かなかった。掘削に伴う計測は，先行沈下計（S-1）で の天端沈下量と地表から設置した多段式傾斜計（T-1, $\mathrm{T}-2$ ) による側壁変位量など掘削以前から行える地盤変 位の測定を主とし, その他, 図一4( b ) に示す計測を行っ た. 支保は 1 スパン $(1.44 \mathrm{~m})$ 遅れで施工したが, 立 坑施工時と同様に上半部掘進時における吹付けモルタル 


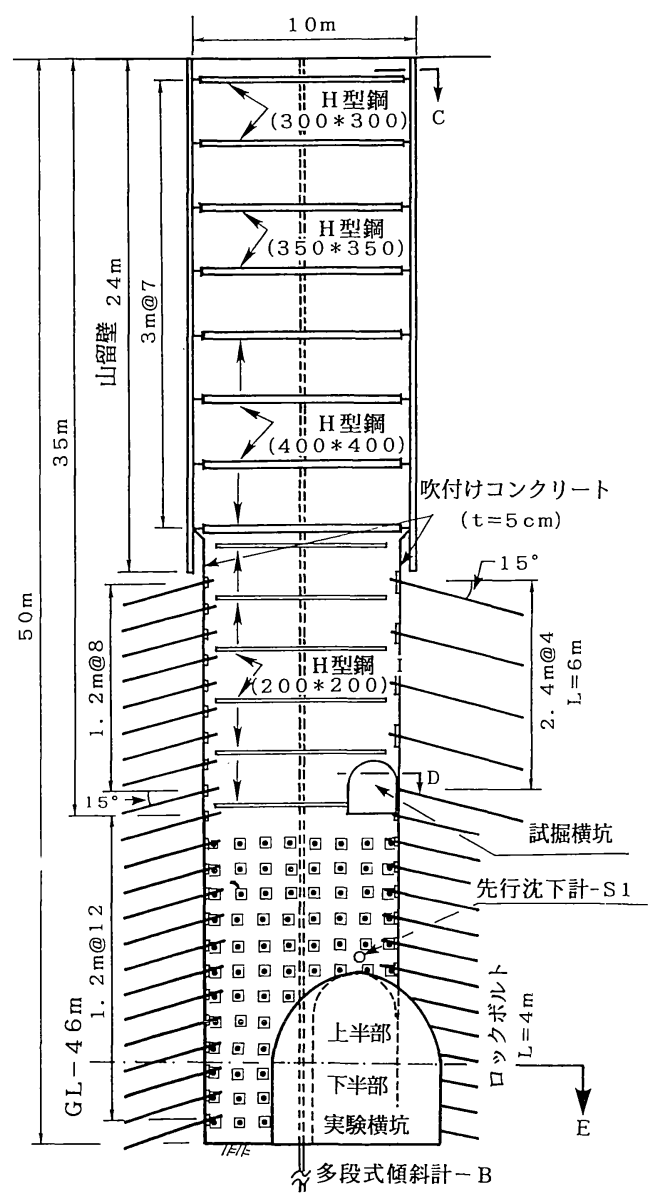

図一３立坑構造図（立面図）

の応力およびロックボルトの軸力は微小であった.つま り, 横坑でも上半部掘削時には支保工の剛性が地盤変形 抑制に寄与していないことを示している.

横坑の断面形状を図一1 に示す. 相似形状の B, C, E 横坑の変形から, 坑寸法が大きくなるにしたがって地盤 内のひずみが大きくなり，[地盤変形/坑寸法]の比が大 きくなる寸法効果があるかどうかを調べた，仮に亀裂等 による不連続体的挙動が卓越するならば顕著な寸法効果 が現れるはずである. 原地盤内でも，三軸試験結果が示 したように応力〜ひずみ関係が圧カレベルの影響を受け ず11,2)，また連続体的挙動をすればこれは現れないこと になる．相対地中変位計による壁面からの相対変位と坑 寸法の比の測定結果は, 上記の寸法効果は工学的に見て 比較的小さい結果を示した（図一5).

\section{4. 原位置試験}

\section{（1）平板載荷試験}

深度 $35 \mathrm{~m}$ の試掘横坑での試験" ${ }^{1}$ と同様に, 堆積軟岩 の変形特性を求め, 他の原位置試験および室内試験と比

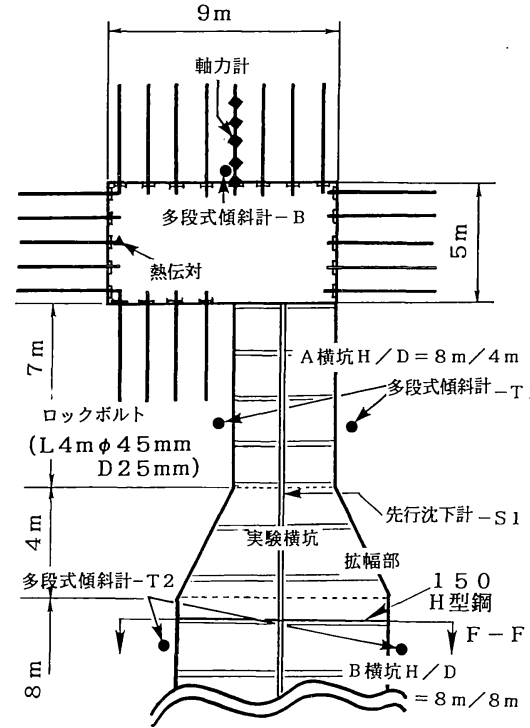

(a) $\mathrm{E}-\mathrm{E}$ 断面（図一-3に位置を示す）

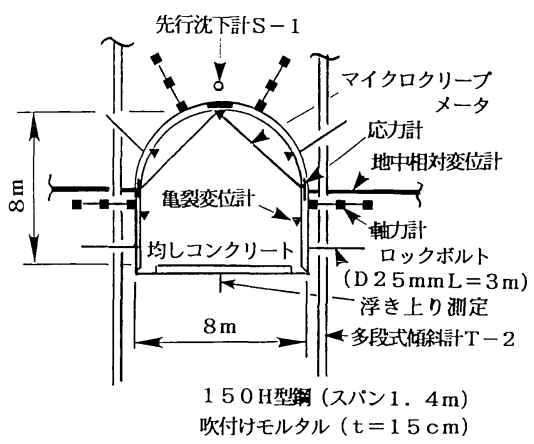

(b) F-F 断面 (図一-1に位置を示す)

図一4 支保工構造図（断面図）

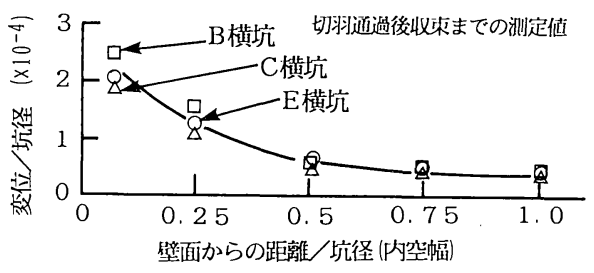

図一5 相対地中変位の分布

較検討し, さらに地盤の連続体としての挙動を詳細に確 認する目的で平板載荷試験を行った。 載荷に伴う地中の ひずみ分布を詳細に調べるため図一6に示すような 11 個の軸方向ひずみ計を埋設した. また, 一般に岩盤の場 合には直径 $60 \mathrm{~cm}$ の載荷板（以下 D 60) が，土質の場 合には直径 $30 \mathrm{~cm}$ の載荷板（以下D 30）が用いられる 場合が多く, ともに等変位載荷法である. 岩盤でより大 きな載荷板を用いる理由は，不連続面の影響を含んだ原 地盤の特性をなるべく正確に求めようとするためであ る.しかし，連続体挙動をする場合は，ことさら大きな 


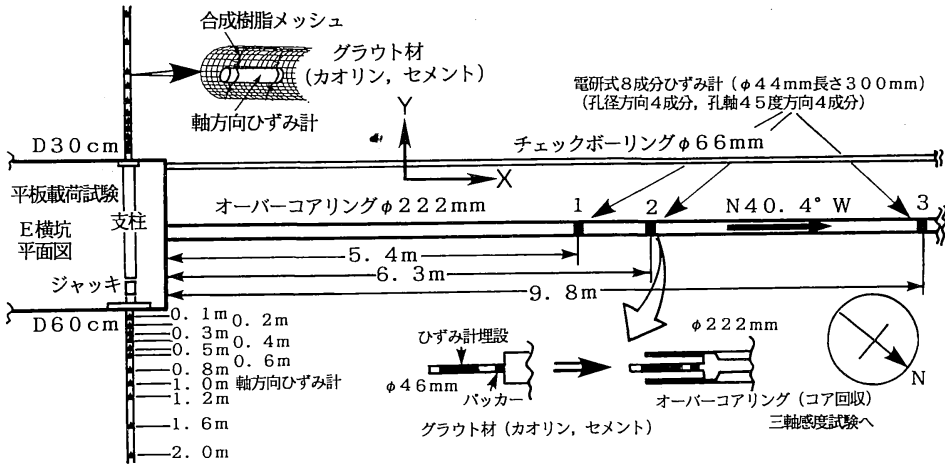

図一6 原位置試験の概要

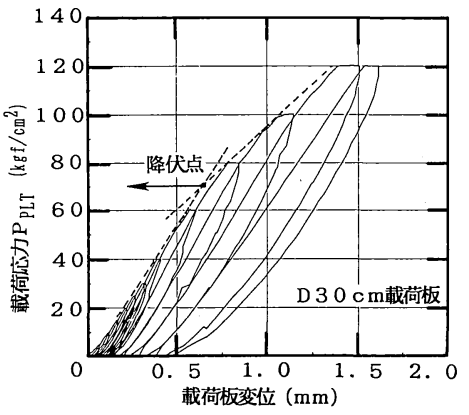

図一7 平板載荷試験結果（D 30)

載荷板を使用する理由はない，今回は，載荷板径の違い の直接的な影響を調べるため，上記 2 㮔類の載荷板を同 時に使用して載荷した．載荷方式は文献7）にしたがっ た. 載荷初期は D 30 に対する載荷方式で行い，次に D 60 に対する載荷方式で載荷した，その結果，D 30 での 載荷応力は最終的に $120 \mathrm{kgf} / \mathrm{cm}^{2}(12 \mathrm{MPa})$ に至り, $70 \mathrm{kgf} / \mathrm{cm}^{2}(7 \mathrm{MPa})$ 付近で降伏点が見られた（図一7).

図一8に載荷板平均圧力～載荷板変位/載荷板直径比 関係を示す．両者は基本的に類似であり，特に寸法効果 はみられない。しかし，いずれの場合も線形弹性連続体 之は異なり，載荷初期に上に凹な形状を示し，塑性変形 も小さくはない。これは載荷面近くの地盤が乱されたこ とと, 載荷板之地盤のなじみが不完全なためのエラー(両 者を合わせてべディングエラー，以下 BE）のためと思 われる. 載荷初期のこの凹の程度は D 60 の方がやや大 きいことから，載荷板変位の読みを用いる方式では，必 ずしも載荷板の径が大きい方が良い結果が得られるとい うことはないようである。なお，今回の試験での BE は深度 $35 \mathrm{~m}$ 位置の試験1) りりも大きかった。このこと は，BEには偶発的要因が大きいことを示している.

一方，図一9に示す地中ひずみ計による測定結果は, 図一8 亡は異なり両者之も同様な非常に線形弾性的であ る.同一深さでは，D 60 の方が D 30 よりもひずみが大 きく，ばらつきが少ない結果が得られているが，これは 載荷板の大きい方が応力が地中深部まで伝わった結果と 思われる. 図一10 は地中ひずみの深度分布の測定結果 之等変位載荷における剛体円盤中心下の弾性解 ${ }^{7), 1+)}$ (ポ アソン比 $\nu=0.33 ， 0.5 ）$ を正規化した上で比較したも のである。この図から，D 30 の場合に載荷板付近のひ ずみがやや理論解よりも小さいものの, 全体的傾向は弾 性解と良く一致している. 理論解よりも測定ひずみが小 さいのは, $\mathrm{BE} に よ り$ 載荷板変位 $\delta$ が過大評価されてい るからであろう。また，両者（D 60，D 30）の結果は非 常に似かよっていて, クラック・ジョイントが存在する 一般的な硬岩での結果とは非常に異なり, 当軟岩地盤で

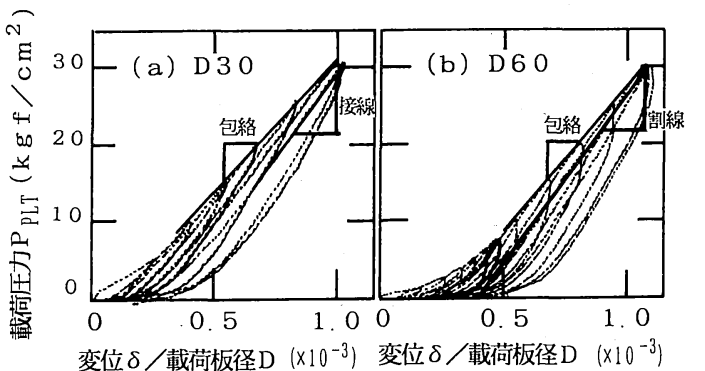

図-8 平板載荷試験結果の比較
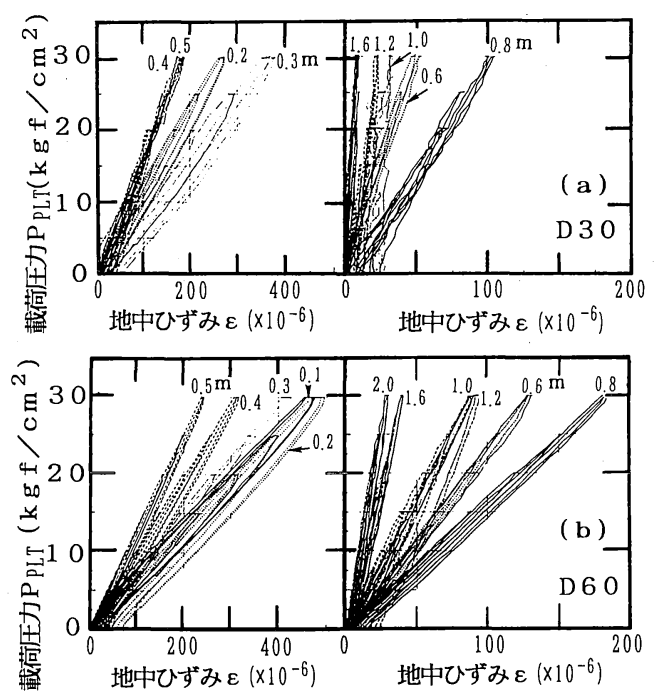

図一9地中ひずみ測定結果

は，連続体としてひずみ（応力）の伝達がなされている ことを示している.

通常の方法 ${ }^{77} に よ り$ 得られた変形係数・弾性係数を比 較すると（表一2，図一8），いずれも D 30 の結果の方が やや小さい，この差は主に，D 30 の方が載荷圧 $P_{P L T}$ が 大きくなってからの BE の影響が大きいためであろう (同一の $\mathrm{BE}$ でも D が小さい方が，比 $\mathrm{BE} / \mathrm{D}$ は大き い). また D 60 での変形係数・弾性係数が大きいという 


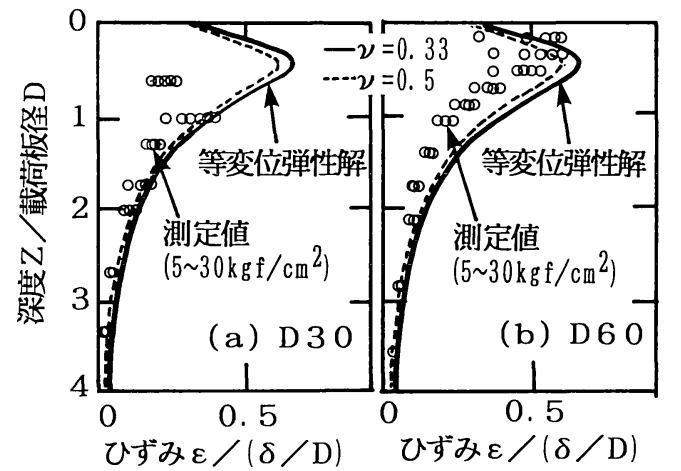

図一10 地中ひずみ分布
表一2 平板載荷試験による変形係数

\begin{tabular}{|c|c|c|}
\hline \multicolumn{2}{|c|}{ D $30 \mathrm{~cm}$ 径平板載荷試䓡, $\nu=0.5$} & ひずみ $\delta / D$ \\
\hline 変形係数 $\mathrm{E}_{\mathrm{PLT}}, \mathrm{D}$ & $18,000 \mathrm{kgf} / \mathrm{cm}^{2}$ & $0.0793 \%$ \\
\hline 接線弾栍沓数 & $25,000 \mathrm{kgf} / \mathrm{cm}^{2}$ & $0.0233 \%$ \\
\hline 割線弾㛗係数 & $22,000 \mathrm{kgf} / \mathrm{cm}^{2}$ & $0.0803 \%$ \\
\hline 変形保数 $\mathrm{E}_{\mathrm{PLT}}, \mathrm{D}$ & $16,800 \mathrm{kgf} / \mathrm{cm}^{2}$ & $0.3 \%$ \\
\hline \multicolumn{2}{|c|}{ D $60 \mathrm{~cm}$ 径平板截荷試験, $\nu=0.5$} & ひずみ $\delta / D$ \\
\hline 変形俰数 $E_{\mathrm{PLT}, \mathrm{D}}$ & $23,500 \mathrm{kgf} / \mathrm{cm}^{2}$ & $0.0625 \%$ \\
\hline 接線弹性俰数 & $32,000 \mathrm{kgf} / \mathrm{cm}^{2}$ & $0.0183 \%$ \\
\hline 割線弹胜俰数 & $27,000 \mathrm{kgf} / \mathrm{cm}^{2}$ & $0.0655 \%$ \\
\hline
\end{tabular}

注；D， $E_{t} ， E_{8}$ はそれぞれ図一7に示す包絡, 接線, 割線の公泪から求めた

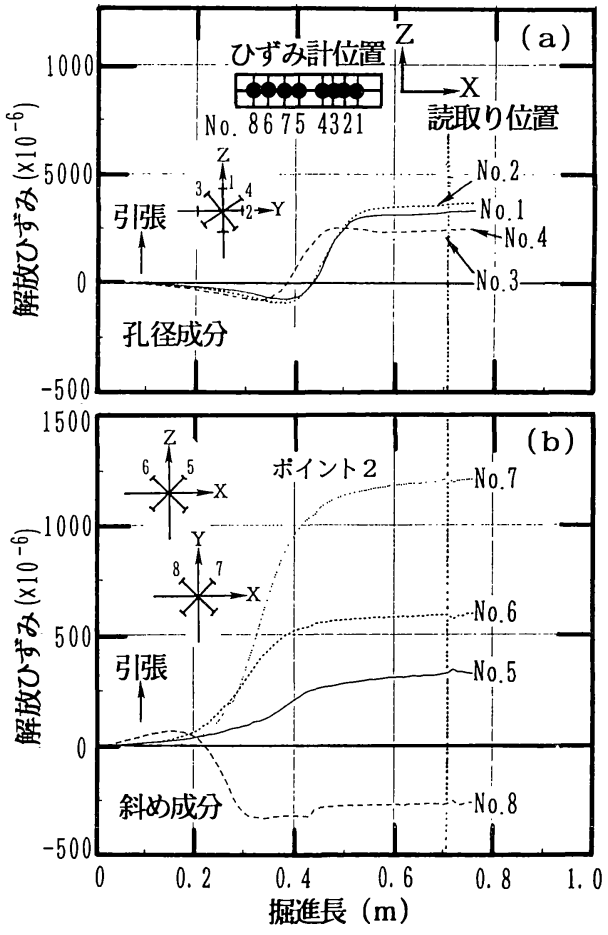

図一11 オーバーコアリングによるひずみ

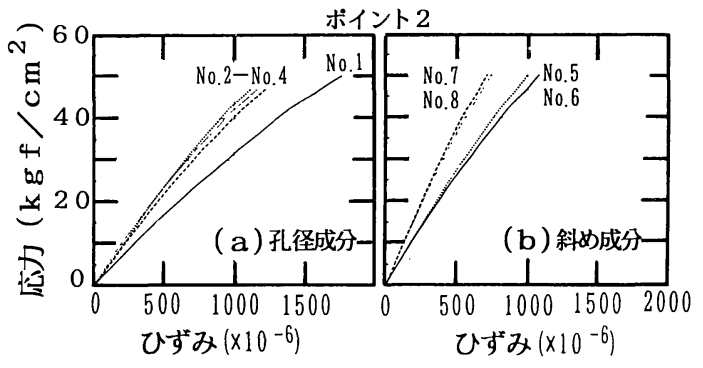

図一12 三軸等方圧力によるコアの感度試験
ことは, 地盤内の不連続性の要因とは逆の結果である. 以上のことから，このような泥岩の平板載荷試験におい て, 載荷板径の影響は小さいと思われる.

\section{（2）初期地圧測定}

掘削に伴う横坑壁面での相対地中変位や平板載荷試験 結果から見ると, 当泥岩層は連続体的な挙動をしている. すなわち, 掘削による地盤変位は初期地圧の解放に伴う 連続体の変形として解析できると考えられる.このよう な解析では, 初期地圧の値亡その主方向の把握は不可欠 である，そこで，国内では実績が多く地圧測定法として は一般的であり，ひずみゲージが接着できない軟岩でも 適用できる 8 成分埋設ひずみ計を用いたオーバーコアリ ングによる初期地圧測定 ${ }^{81,3)}$ を, 測定位置は図一13のモ デルの弾性解析により立坑および横坑の影響が無視でき ると判断できる深度で行った (図一6). 図一11に解放 ひずみと掘進長の関係の代表的結果を示す（ポイント 2). ゲージNo.1〜No. 4 は孔径成分で，ゲージNo. 5 〜No. 8 は孔径方向から斜め $45^{\circ}$ 成分である. この結果 はポイント 3 でもほぼ同様であった。なおポイント 1 で の結果は，ゲージの接触による不安定な出力が多かった ので地圧の算定には使っていない. 図中に示す定常状態 でひずみを読取り，解放ひずみとした。

図一12 にコアの等方圧力による三軸感度試験結果 ${ }^{31,81}$ を示す。この等方応力〜埋設ひずみ関係群から，初期の 勾配 (応力/ひずみ) の平均值を用いて, 図一11 の解放 ひずみから初期地圧の 6 応力成分を同定した

表一3に同定された初期地圧の大きさと方向を示す. 同表で $X$ 方向は横坑軸線方向である（図一2, 図一 6 ). 表一3 より最大圧縮軸（ $\sigma_{1} ）$ 方向はほぼ水平面内でほぼ 東西を向いており，同じくほぼ水平面内に最小圧縮軸 $\left(\sigma_{3}\right)$ が存在している.この両者の值には 3 倍近い差が あり，初期地圧に大きな異方性がある結果となった。こ の異方性は，掘削による地盤の変形特性を評価する上で 無視し得ない.また，表一1に示した断層系の明瞭なせ ん断性割れ目はほぼ鉛直であり，かつ上記 $\sigma_{1}$ 方向之約 


\begin{tabular}{|c|c|c|}
\hline \multicolumn{3}{|c|}{ 表-3 初期地圧測定結果 } \\
\hline 最大圧縮主応力 $\sigma_{1}$ & $30.9 \mathrm{kgf} / \mathrm{cm}^{2}$ & $\mathrm{~N} 104^{\circ}$ E $3.9^{\circ} \mathrm{W}$ \\
\hline 中間王縮主応力 $\sigma_{2}$ & $18.2 \mathrm{kgf} / \mathrm{cm}^{2}$ & $\mathrm{~N} 148^{\circ}$ W77. $5^{\circ} \mathrm{N}$ \\
\hline 最小压縮主応力 $\sigma_{3}$ & $10.7 \mathrm{kgf} / \mathrm{cm}^{2}$ & $\mathrm{~N} 13^{\circ} \mathrm{E} 11.8^{\circ} \mathrm{S}$ \\
\hline$X$ 軸方向応力 $\sigma_{x}$ & $29.7 \mathrm{kgf} / \mathrm{cm}^{2}$ & \\
\hline$Y$ 軸方向応力 $\sigma_{Y}$ & $12.2 \mathrm{kgf} / \mathrm{cm}^{2}$ & \\
\hline Z軸方向応力 $\sigma_{z}$ & $18.0 \mathrm{kgf} / \mathrm{cm}^{2}$ & \\
\hline $\mathrm{X}-\mathrm{Y}$ せん断力 $\tau_{\mathrm{XY}}$ & $-4.5 \mathrm{kgf} / \mathrm{cm}^{2}$ & \\
\hline $\mathrm{Y}-\mathrm{Z}$ せん断力 $\tau_{\mathrm{YZ}}$ & $-1.6 \mathrm{kgf} / \mathrm{cm}^{2}$ & \\
\hline $\mathrm{Z}-\mathrm{X}$ せん断力 $\tau_{z \mathrm{x}}$ & $0.4 \mathrm{kgf} / \mathrm{cm}^{2}$ & \\
\hline
\end{tabular}

$25^{\circ}$ 傾いているので，この断層系割れ目の成因が地質構 造的なものであるとするならば，この璟方的初期地圧と よく対応している.

しかし, $Z$ 方向 (鉛直) の初期地圧が $18 \mathrm{kgf} / \mathrm{cm}^{2}(1.8$ $\mathrm{MPa}$ ) であり, 平均土被り圧 $10 \mathrm{kgf} / \mathrm{cm}^{2}(1 \mathrm{MPa})$ の 2 倍近い. 当泥岩が見かけ上超過圧密 (泥岩上面と碩層 は100万年の差がある不整合と推定）であり超過上載圧 が部分的に残っていたり, 最大圧縮応力の上下方向の傾 きの影響がでている可能性がある. しかし, 続成作用に よりセメンテーションが生まれた可能性もあるので, 結 論はできない。一方, 図一12に示す結果から地盤の剛 性を逆算する際に等方等質線形性を仮定している.この 方法は, マイクロクラックや充填材の不均一性が解放ひ ずみに与える影響を除去するために行われている方法 ${ }^{3)}$ であるが，このことは同時にコアの変形特性の異方性や 非線形性を無視することになる．例えば図一12の応力/ ひずみ勾配の相違が物性の異方性を示していると考える と, $Z$ 方向の応力は $70 \%$ 程度に減少する.この值はほ ぼ土被り圧と等しい。すなわち, 地圧の方向とその異方 性は図一11 の解放ひずみで確認できるが，このひずみ 加ら正確な初期異方的応力状態を求めるには, 異方性物 性に対する正確な構成則が必要となる.

\section{5. 変位計測結果と解析}

立坑が多段式傾斜計一B, 横坑が先行沈下計一 $\mathrm{S} 1$ と 多段式傾斜計一 T1, T2により, 掘削開始から地盤変位 を計測した（図一13）. 図一14に多段式傾斜計一Bによ る立坑の水平変位を示す. 深度 $35 \mathrm{~m}$ 以深の立坑掘削は 1992 年 3 月 16 日から行っており, 同年 9 月 16 日に床 付けコンクリートが打設された. 深度 $35 \mathrm{~m}$ から $50 \mathrm{~m}$ までの掘削に伴う立坑水平変位は $3 \mathrm{~mm}$ 程度と非常に小 さかった。また,この掘削による影響は, 深度 $32 \mathrm{~m}$ 付 近までしかなく,それ以浅は変位増加が見られなかった。 前述したように, 掘削に伴うロックボルトの発生軸力は 掘削解放応力と比べてはるかに小さく $[100 \mathrm{kgf}(1 \mathrm{kN})]$,

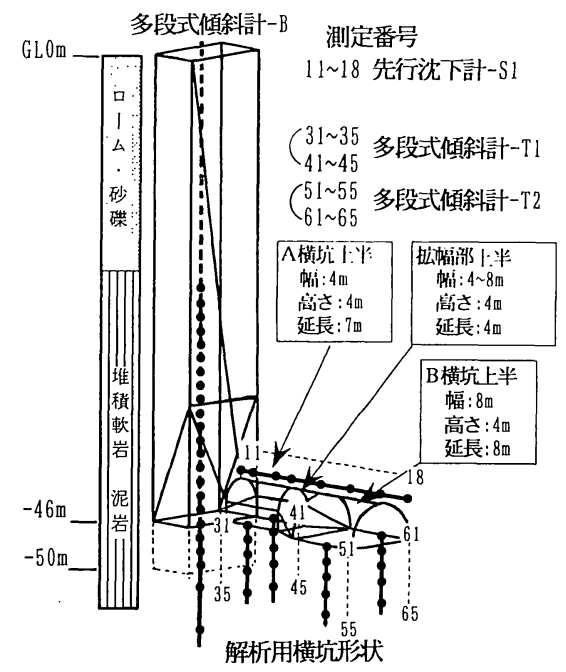

図一13 現場計測の概要と BEM モデル

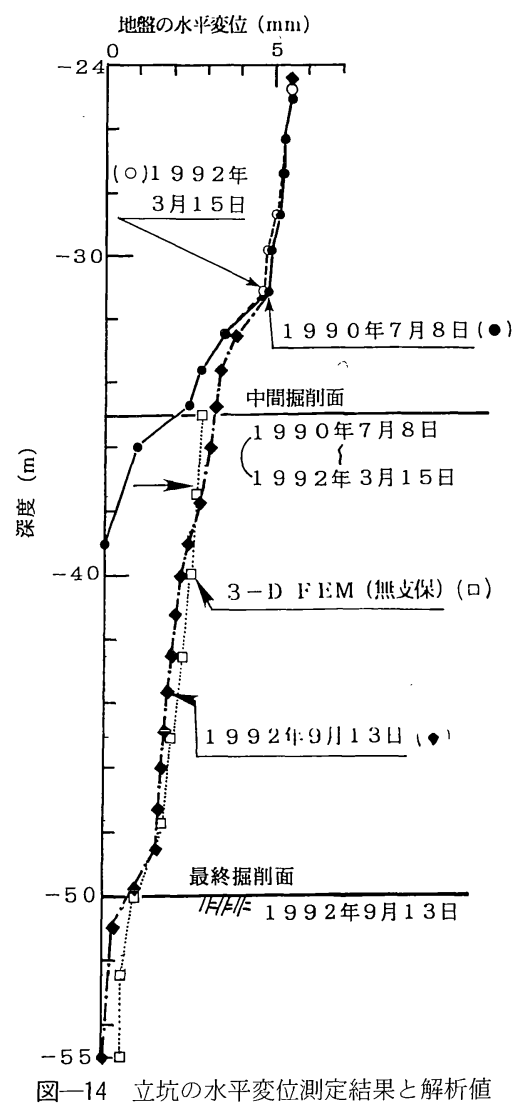

表一4 立坑変位から逆算した変形係数

\begin{tabular}{|c|c|c|c|}
\hline & 初 期 応 力 & $\mathrm{E}_{\mathrm{BA}(\mathrm{s}) ; \mathrm{kgf} / \mathrm{cm}^{2}}$ & 記号 \\
\hline$(1)$ & 地圧測定值 & 36,000 & $\square$ \\
\hline$(2)$ & $\gamma \mathrm{H}, \mathrm{K}=2$ & 25,000 & $\square$ \\
\hline$(3)$ & $\gamma \mathrm{H}, \mathrm{K}=1$ & 12,500 & $\square$ \\
\hline
\end{tabular}




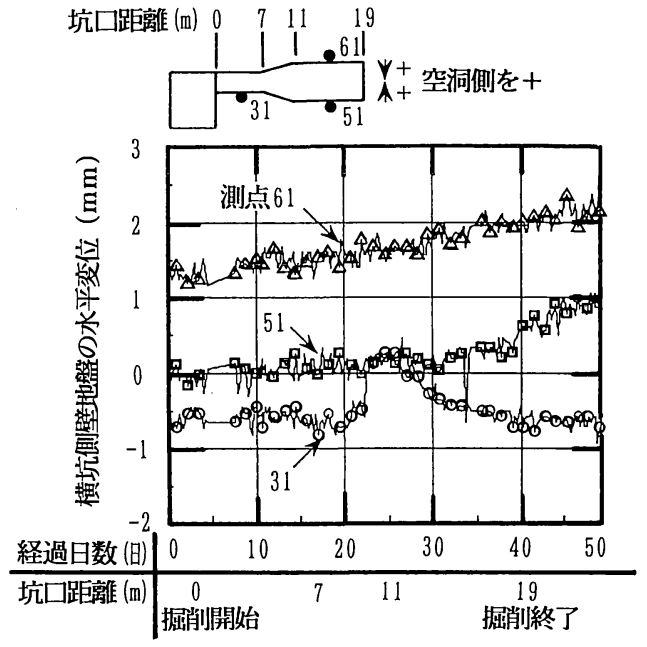

図一15 横坑側壁の変位測定結果

変形抑制にはほとんど寄与していないと考えられるの で, 無支保の状態で 3 次元 FEM 解析を行った ${ }^{91}$. 解析 モデルは文献1）によるものと同様で泥岩は等方線形均 質弾性体（ポアソン比 $\nu=0.3$ ) と仮定した。深度 $35 \mathrm{~m}$ 掘削時を初期状態として $50 \mathrm{~m}$ 掘削時における変位を解 析した。なお，静水圧や流水圧は考慮していない。図一 14 に示すように解析結果と実測值は良く対応しており, 解析上の最大ひずみは $\varepsilon_{\max }=0.04 \%$ 程度であった。

次に上記解析で逆算された[深度 $50 \mathrm{~m}$ 位置での $\sigma_{h}=$ $\sigma_{x}$ ] / [線形変形係数 $\left.E_{B A(S)}\right]=8 \times 10^{-4}$ に対して, $E_{B A(S)}$ を次の 3 つの条件で求めた.（1）表一3に示す $X$ 方向 の応力をそのまま用いた場合 $(\boldsymbol{\square}),(2)$ 土被り圧 $\left[\sigma_{v}\right.$ $\left.=\sigma_{z}=\gamma H, \gamma=2.0 \mathrm{tf} / \mathrm{m}^{3}\left(20 \mathrm{kN} / \mathrm{m}^{3}\right)\right]$ に対して, 地圧測 定での側圧係数 $K=\sigma_{x} / \sigma_{v}=2.0$ とした場合（四，（3） 同じくKを最も単純に 1 とした場合 $(\square)$ で，これら の結果を表一 4 に示す.

さらに，図一13に示す BEM モデルで，横坑上半部 掘削に伴う変位計測結果を用いて, 線形逆解析を行った。 図一15に多段式傾斜計一 T1，T2 による掘削に伴う側 壁地盤の水平変位測定結果を示す. 掘削に伴う側壁の腹 み出しは非常に小さく, $1 \mathrm{~mm}$ 弱であった。一方，図一 16 には差圧計により基準水位タンクと沈下測定点との 水頭差の変化を計測した先行沈下計一S1 による天端沈 下量の計測結果を示す. 図一16( a ) は坑口から A 横坑 の結果を, また $(\mathrm{b})$ 図には拡幅部・B横坑の測定結 果を示す.まず，この図より坑口付近から $\mathrm{A}$ 横坑の掘 削によりかなり先端（測点 16）までその影響がでてい ることが分かる. その後の拡幅部以深の掘削では, 切羽 の通過に伴う沈下量が支配的となる. 沈下量の最大值は $6 \mathrm{~mm}$ 程度であり, 側壁の腹み出しよりは相当大きかっ た.
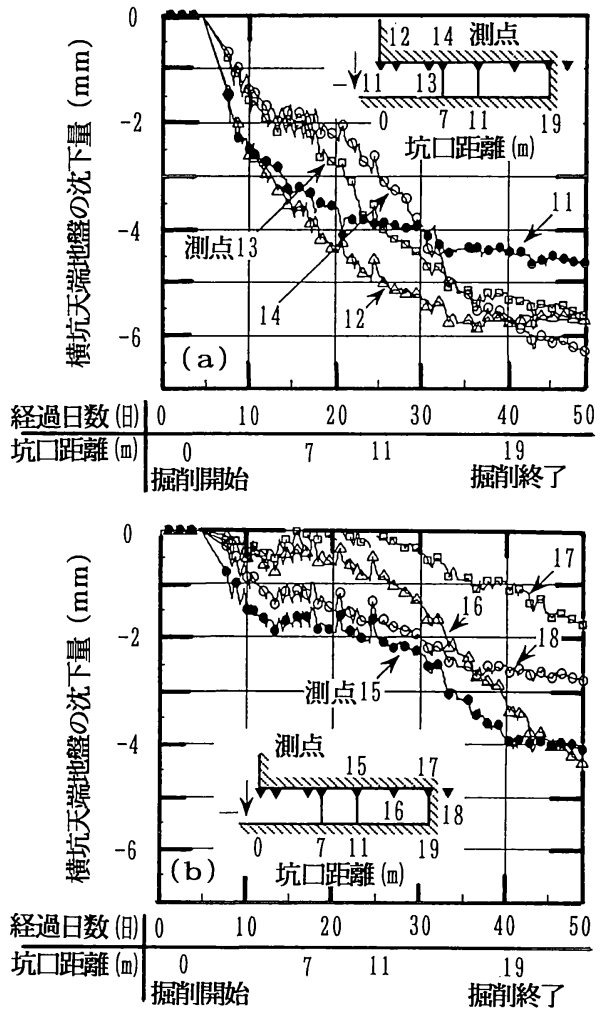

図一16 横坑天端沈下の測定結果

横坑上半掘削時にはロックボルト軸力や覆工応力はほ とんど発生しなかったのでこの効果を考慮せず，一様な 線形弾性体（ポアソン比 $\nu=0.3$ ) と仮定した BEM で, 立坑掘削時を初期状態として $\mathrm{A}$ 横坑上半から $\mathrm{B}$ 横坑上 半掘削に至る変形の逆解析を行った。図一17に逆解析 結果と計測結果の比較を示す。この際，(a) 沈下デー 夕 7 つと水平変位デー夕 3 つの重み付けを 1 つ 1 つ同一 とした場合と（b）デー夕群に対して同等の重み付けを した場合とを検討したが，両者に大きな差はなかった。 以下では ( a ) の結果を用いる.この図より, 天端沈下 でのピークの位置がややずれていることや側壁の変位形 態に差があることなどがあるものの，ひずみレベルが $0.1 \%$ 台と当該泥岩にとっては比較的大きい( ${ }^{11,2}$ にもか かわらず, 線形変形係数による解析值は解析値亡良く一 致している. 解析上のひずみは $\varepsilon_{\max }=0.18 \%$ であり, パラメータ $\left(\sigma_{v}=\sigma_{z}\right) / E_{B A(T)}$ と $\sigma_{Y} / E_{B A(T)}$ はそれぞれ $5.8 \times 10^{-+}$と $1.2 \times 10^{-3}$ である. 立坑と同様に次の 3 つ を仮定して線形変形係数 $E_{B A(T)}$ を求めた. 初期応力条 件は全応力での $K$ 値 $=\sigma_{h} / \sigma_{v}=\left[\sigma_{h}^{\prime}+(\right.$ 水圧 $\left.)\right] /\left[\sigma_{v}^{\prime}+(\right.$ 水 圧)]で定義している.（1）地圧測定結果（表一3， $\sigma_{Y}$ と $\left.\sigma_{Z}\right)$ を用いた場合 $(\boldsymbol{\Delta}),(2)$ 鉛直方向に土被り圧 $\sigma_{v}=\gamma H$ を与え, $K=\sigma_{Y} / \sigma_{v}$ の值として地圧測定での $K=$ $\sigma_{Y} / \sigma_{Z}=0.5$ を用いた場合, (3) 単純な土被り圧の静水 

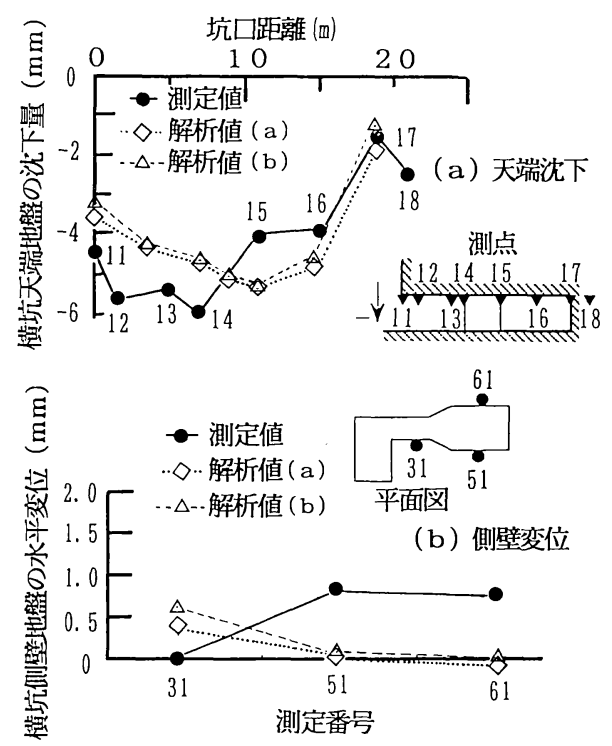

図一17 横坑変位の解析值と実測値の比較

表一5 横坑変位から逆算した変形係数

\begin{tabular}{|c|c|c|c|c|}
\hline & 初期 応力 & $\begin{array}{l}E_{B A}(T) \\
\text { Y成分 }\end{array}$ & $\begin{array}{l}\mathrm{kgf} / \mathrm{cm}^{2} \\
\text { Z成分 }\end{array}$ & 記号 \\
\hline (1) & 地圧测定值 & 19,000 & 15,500 & $\mathbf{\Delta}$ \\
\hline (2) & $\gamma \mathrm{H}, \mathrm{K}=0.5$ & 8,700 & 8,600 & \\
\hline (3) & $\gamma \mathrm{H}, \mathrm{K}=1$ & 17,400 & 8,600 & $\Delta$ \\
\hline
\end{tabular}

圧分布 $(K=1)$ と仮定した場合 $(\triangle)$ である.この結 果を表一5に示す. (2) のケースで $Y, Z$ 成分での $E_{B A(T)}$ が類似なことは，地盤の剛性は等方的なことを示 唆しているが，結論はできない．それは，原地盤が完全 飽和状態であるとすれば， $K=0.5$ は初期有効側圧 $\sigma_{h}^{\prime}$ が ゼロであることを意味し，常識的にはあり得ない值であ るからである。したがって， $K=0.5$ での值は以下では 用いない.

\section{6. 各種変形特性の比較}

前報2゙でも0.001（\%）以下の小さいひずみから破壊 を越えるひずみまで連続的にかつ正確に軸ひずみを測定 した静的な室内三軸試験による変形特性は, ひずみレベ ルに応じていわゆる動弾性係数, 各種原位置試験および 現場解析による変形係数と大略整合することを示した. 今回は地圧の測定を行ったことに加えて, 前回よりもよ い条件で原位置試験が実施できたことなどにより，この ことをより細かく考察することができた。

図一18は, 今回の掘削軟岩地盤の変形係数のひずみ レベル依存性を示したものである， $E_{\mathrm{sec}}$ は，コア試料 の三軸ひずみを供試体側面で正確に測定した圧密三軸試 験で得られた值であり， $E_{\mathrm{sec}} /\left(E_{\mathrm{sec}}\right.$ の最大值 $\left.E_{\max }\right) \sim$ $\log \varepsilon_{1}$ 関係の平均曲線（文献2）の図一11）を，非排水
試験 $(C U)$ と排水試験 $(C D)$ に分けて示してある. $E_{f}$ は原位置せん断弾性波速度加ら求めたいわゆる $\left[\right.$ 動弾 $^{\circ}$ 性係数 $]=32,170 \mathrm{kgf} / \mathrm{cm}^{2}(3,150 \mathrm{MPa})$ であり ${ }^{2)}, E_{\max }$ $=E_{f}$ を仮定している. $E_{P L T}$ はD 30 とD 60 による平板 載荷試験の結果で, 地中ひずみによるもの $(S)$ と平板

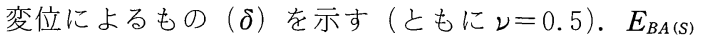
と $E_{B A(T)}$ は表一 4 , 表一 5 に示す地盤変位の逆算による 線形変形係数である.さらに， $E_{B H L T}$ は深度 $50 \mathrm{~m}$ での 孔内載荷試験による結果である $(\nu=0.5)$. 空洞ひずみ $\varepsilon_{c}=($ 孔壁変位 $u) /\left(\right.$ 初期孔半径 $\left.r_{0}\right)$ である. なお, 前報 ${ }^{1}$ において孔内水平載荷試験での除荷・再載荷部の結果を 従来の方法10)で解釈すると不都合が生ずることを示した が，今回は図一19に示す方法で求めた。つまり，応力 $\sim \varepsilon_{c}$ 曲線での持続的クリープか圧密の影響が大きい除 荷直後の曲線部分を除いた部分に対する接線勾配から割 線変形係数 $\left[G_{\mathrm{sec}}=E_{\mathrm{sec}} / 2(1+\nu)\right]$ を直接求めた ${ }^{111}$. この 結果, 除荷時の $E_{B H L T}=E_{\mathrm{sec}}$ が $0.1 \%$ 以下のひずみレベ ルで桁違いに大きくはなく, 他のデータとの整合性も良 くなった。なお，今回原位置試験で $\nu=0.5$ を用いたの は，図一10に示したようにレ=0.5に対する理論解が実 測值に近いことによる.

平板載荷試験の結果 $E_{P L T(S)}$ 亡 $E_{P L T(\delta)}$ は，ほぼ同一の ひずみ依存性関係にプロットされている.これは， $B E$ の影響で $E_{P L T(\delta)}$ の值は実際よりも小さめになっている が, $\varepsilon_{1}=\delta / D$ も実際のひずみよりも大きめになっている ためである (図一10参照). 測定地圧を用いた逆解析值

（口，、）の変形特性はやや大きく，これに対して鉛直 応力に土被り圧を用いて $K=1$ とした逆解析値 $(\square, \triangle)$ は若干小さめの值である. $\sigma_{v}=\gamma H$ を用いた場合, $K=$ $\sigma_{X} / \sigma_{v}, \sigma_{Y} / \sigma_{v}$ はいずれも $1 \sim 2$ の值だとデー夕の整合性 が良い. 図一18を全体的に見ると, 本堆積軟岩ではコ アの物性を用いた非線形連続体解析手法が適用できるこ とを示している.

図一20は，各変形係数を応力レベル(荷重係数) に 応じて表示したものである。ここで， $q / q_{\max }$ は三軸試 験での偏差応力 $\left(\sigma_{1}-\sigma_{3}\right)$ と圧縮強度 (図一3) の比を 表わす. $q / q_{\max }$ は安全率の逆数なので, このような整 理をすれば設計変形係数と安全率の関係が明確になり, 実務的に有効であると思われる，平板載荷試験は円盤の 支持力問題と考えられる. 内部摩擦角 $\phi$ がゼ口の場合 の Terzaghi の支持力 ${ }^{12)}$ は $7.4 c=3.7 q_{\max }$ で与えられる ので, 平均圧力 $P_{P L T} / 3.7$ が $q_{\max }$ と比較すべき応力と考 えられる. 孔内水平載荷試験では図一19より, 非排水 条件の場合, $\mathrm{a}$ 点におけるひずみ増分 $\Delta \varepsilon_{c}$ に対するせん 断応力 $\tau_{B H L T}$ は $\mathrm{AB}$ 間の増分圧力 $\Delta P_{B H L T}$ に等しくな る $^{13)} .2 \times \tau_{B H L T}$ および逆解析値のせん断力 $\tau_{B A}$ も $E_{B A} \times$ $\varepsilon_{B A}$ として $q_{\max }$ に対応する応力レベル $q$ とした.

この図より, 原位置試験および現場挙動の応力レベル 


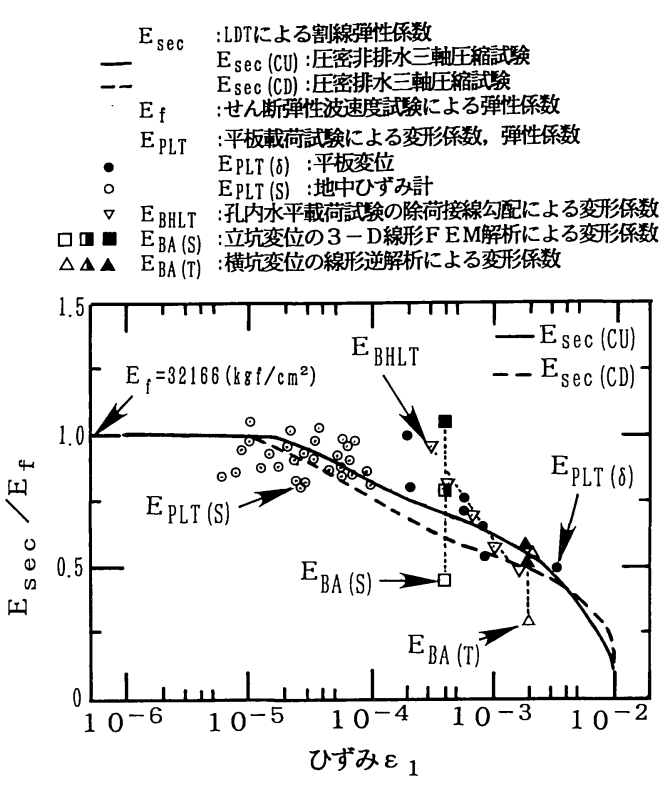

図一18 変形特性のひずみレベル低存性

がほぼ 0.5 より小さいことが分かる，また，この整理法 でも図一18 と同様な傾向が見られる．室内三軸試験で は応力レベル 0.1〜0.9 の広範囲において, 変形係数の 変化が小さい（区間線形関係に近い）。同様の傾向は他 の原位置試験や逆解析値でも見られる（特に孔内水平載 荷試験)。今回行った線形連続体解析の結果が実測値と 比較的良い対応を示したのは，この泥岩の区間線形特性 によるものと思われる.の応力レベルでの変形係数は[真 の弾性変形係数 $]^{21} E_{f}$ の $1 / 2$ に近い. 図一20 加らも全体 的に見て,各々のデー夕の整合性はかなり良いといえる. より詳細には現場試験之現場挙動における排水条件の影 響を考慮する必要がある。また，初期応力状態 $K$ 值は 1 以上であることを示唆している．しかし，原地盤内の 初期応力状態之物性の異方性のさらなる検討が必要であ る.これらは今後の課題としたい.

\section{7. ま め}

泥岩内の深度 $50 \mathrm{~m}$ の空洞の掘削概要を示し，地盤変 位の数值解析および初期地圧測定および平板載荷試験な ビの原位置試験と室内試験による変形特性を総合的に比 較検討した．得られた結論を以下に要約する。

（1）掘削工事での地盤変位は，通常の一軸圧縮試験 による $E_{50} \doteqdot 3,000 \mathrm{kgf} / \mathrm{cm}^{2}(290 \mathrm{MPa})$ を用いた事前の 解析で予測された値の 5 分の 1 程度と, 非常に小さい地 盤変位しか生じなかった。このことは泥岩の剛性は従来 考えられていたよりもはるかに大きいことを示してい る. 特に, 比較的大深度での横坑の経済的構築工法の可 能性が確認できた（図一-3，図一4）。

（2）地圧測定の結果からは，ほぼ東西方向の最大軸

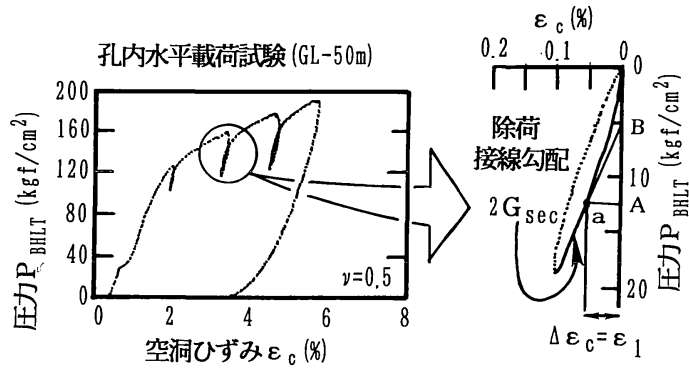

図一19 孔内水平載荷試験の結果の解瀵

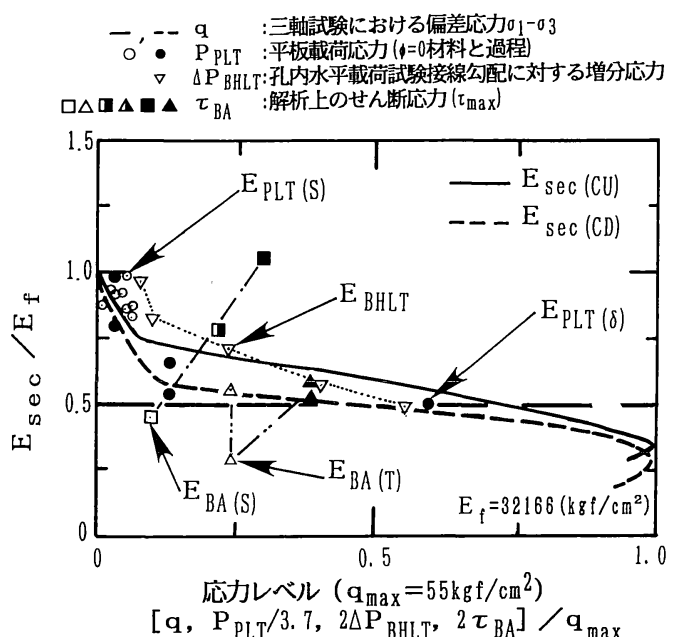

図一20 変形特性の応力レベル依存性

圧縮応力は最小応力の 3 倍近く (表一-3), 水平面内で地 圧の異方性を示した. また，横坑の変形の逆解析値も水 平面内の地圧の異方性を示唆した（表一5）.

（3）載荷板径の異なる $(30 \mathrm{~cm}$ 之 $60 \mathrm{~cm})$ 平板載荷 試験を実施した（図一 6). 載荷板の変位を読む方法では, 偶発的なベディングエラーのため, 変位が過大評価され る可能性がある．また，必ずしも載荷板径の大きい方が 良い結果がでるとは限らなかった（図一7）。さらに，地 中軸ひずみ分布を詳細に測定した結果，両者の差はなく 連続体に近い測定結果が得られた（図一10).

（4）変形特性のひずみレベル依存性を比較すると, 全体として室内三軸試験結果と原位置試験および現場逆 解析値はよく整合した（図一18)。すなわち，当該軟岩 地盤の挙動はコアの物性（非線形連続体）により評価で きる.また，地盤の変形特性の逆解析值は初期地圧の設 定值に強く支配される. 全体として初期水平応力は，平 均上載圧よりも大きいことを示唆する結果が得られた。 すなわち，構造物の設計に際しては，地盤の変形特性と ともに初期地圧状態を仮定ではなく正確に把握する必要 があるが，その推定は簡単ではない。

（5）応力に対する安全率を考慮する上で実務上有効 
である応力レベルと変形特性の関係を比較したところ, （4）と同様の結果が得られた (図一20). 当堆積軟岩は, 応力レベルの広範囲において変形特性が区間線形である ことが確認できた

（6）今回行った実物大の規模で，また，従来の設計 法に従う場合と比較すると相当軽い支保工を用いた試験 掘削においても, 地盤内に生じたひずみレベルは最大で $0.2 \%$ 程度であり, 応力レベルはコア試料の最大強度に 対して 0.5 以下であった. 以上のことは，この種の地盤 の設計問題において, 応力の安全率 2 以上の状態で $0.1 \%$ 以下の微小ひずみレベルでの変形特性の正確な評 価が重要であることを示している，その方法として，原 位置せん断弾性波速度から求めた变形特性 $\left(E_{f}\right)$ を活 用する方法が有効であることが分かった。

最後に, 本研究にご協力頂きました東急建設 (株) 常 田左門氏, 成行㧝氏, 中村和之氏, 西岡哲氏, 応用地質 （株）田中荘一氏始めコアラボの方々, 韓国調達省金有 性氏（元東京大学大学院生）には，末筆ながら感謝の意 を表します。

\section{参 考 文 献}

1）越智建三・壶内達也・龍岡文夫：立坑掘削と原位置試験 による堆積軟岩の変形特性, 土木学会論文集 No.463/ III -22, 土木学会, pp. 143 152, 1993.3.

2）越智建三・金 有性・龍岡文夫：ひずみ依存性と測定誤 差を考慮した堆積軟岩の変形特性の検討, 土木学会論文 集 No. 463/III-22, 土木学会, pp. 133 142, 1993. 3.

3）土木学会編 : 初期地圧測定法の現状と課題, 1992.

4) 越智建三・壹内達也 - 龍岡文夫 : 堆積軟岩中の実験空洞 の施工 (その 1 ) 一施工概要と地圧測定一, 土木学会第
48 回学術年次講演会, 土木学会, 1993.9.

5）㚍内達也・越智建三・龍岡文夫：堆積軟岩中の実験空洞 の施工 (その 1 ) 一变位計測之逆解析一, 土木学会第 48 回学術年次講演会, 土木学会, 1993.9.

6）越智建三・壶内達也：大深度地下開発フィールド実験一 STUD プロジェクト一, 地下空間利用シンポジウム 1993, 土木学会, 1993.6.

7）土木学会編：原位置岩盤の変形及びせん断試験の指針一 解説之設計への応用一, 土木学会, 1983.

8）金川忠・日比野敏・石田 毅：オーバーコアリング法 による 3 次元地圧測定法一埋設型 8 成分ゲージの開発一, 電力中央研究所報告, 研究報告 : 385033 , (財)電力中央 研究所, 1986.

9) Ochi, K., Tsubouchi, T. and Tatsuoka, F. : Stiffness of sedimentary soft rock from in-situ and laboratory tests and from field behavior, International Symposium on Hard Soils-Soft Rocks, Athens, Sep. 1993.

10）土木学会編：孔内載荷試験法の現状と課題, 土木学会, 1985.

11) Jardine, R.J. : Non-linear stiffness parameters from undrained pressuremeter tests, Canadian Geotechnical Journal, Vol.29, pp.436 447, 1992.

12) Terzaghi, K. : Theoretical soil mechanics, pp.120 133, 1943.

13) Parmer, A.C. : Undrained plane-strain expansion of a cylindrical cavity in cray - a simple interpretation of the pressuremeter test, Geotechniqe, Vol.22, No.3, pp.451 457, Sep. 1972.

14）飯田隆一・柴田 功・西岡 正・斉藤孝三：岩盤変形試 験と内部ひずみ分布特性, 土木学会第 11 回岩盤力学に関 するシンポジウム講演論文集, pp. 46 49, 1978.

(1993.6.7 受付)

\title{
DEFORMATION CHARACTERISTICS OF SEDIMENTARY SOFT ROCK EVALUATED BY FULL-SCALE EXCAVATION, FIELD AND LABORATORY INVESTIGATION AND LINEAR BACK-ANALYSIS
}

Kenzo OCHI, Tatsuya TSUBOUCHI and Fumio TATSUOKA

\begin{abstract}
A deep vertical shaft down to $50 \mathrm{~m}$ and a relatively large-diameter tunnel were excavated in a sedimentary mudstone deposit for research purposes. The deformation characteristics of sedimentary soft rock was studied from field observations and their back-analysis taking into account the initial stress state estimated by the over-coring method. The Young's modulus from the field behavior was very similar to that obtained by various in-situ tests and the triaxial tests when the strain level-dependency of stiffness and shear stress-dependency of that evaluated by the triaxial compression tests are considered. Therefore, in this mudstone deposit, the effects of cracks, joints, faults and the confining pressure are insignificant.
\end{abstract}

